\title{
SPRING WAS REBELLIOUS, BUT IT'S ALL OVER NOW - PUBLIC ART, POLITICS AND THE LAW IN POST-APARTHEID SOUTH AFRICA - PART ONE
}

\author{
Stephen Peté \\ BA LLB LLM MPhil \\ Associate Professor of Law \\ University of KwaZulu-Natal, Durban \\ Attorney of the High Court of South Africa. \\ Sarah Pudifin \\ BA(Hons) LLB LLM MPhil \\ Pupil Advocate at the KwaZulu-Natal Bar
}

SUMMARY

Politics, art and the law make uncomfortable bedfellows. The commissioning of public art by public bodies, in particular, often gives rise to bitter controversy. As a recent ongoing public spat over the suitability of a sculpture of three large elephants in the Durban area attests, South Africa is not immune from such controversy. Using the facts of this particular case as a lens, this article seeks to address the following central question: In the context of post-apartheid South Africa, when public works of art are commissioned by public bodies, to what extent do state officials have the right to involve themselves and/or interfere in the process? After outlining salient details of the Durban elephant sculpture case, part one of this article seeks to situate the central issues raised in their historical and ideological context. It then proceeds to address the issue of the "proper" relationship to be maintained between state officials and public art within a constitutional democracy such as South Africa. A strong case is made that the values of tolerance, openness and diversity should be central in setting the broad parameters of the present debate on this issue. In particular, it is argued that the South African state should adopt a "hands-off" and "arms-length" approach when it comes to the funding and commissioning of public art. Part one of this article concludes with a discussion on the legitimate limits to free artistic expression. 


\section{$1 \quad$ INTRODUCTION}

Beauty, it is said, is in the eye of the beholder. ${ }^{1}$ For this reason, perhaps, works of art, and in particular those works of art commissioned for display in public spaces, are frequently surrounded by vociferous debate, and mired in controversy. Certainly, disputes between patrons and artists over publically displayed art are not new. One famous example concerns a mural entitled "Man at the Crossroads" by Diego Rivera, which was commissioned by Nelson Rockefeller in 1933 to cover an expansive ground-floor wall in the Rockefeller Center in New York City. The mural was to reflect the theme "Man at the Crossroads Looking with Hope and High Vision to the Choosing of a New and Better Future". ${ }^{2}$ The huge mural that was produced by Rivera had many parts: it included depictions of society women drinking alcohol, pictures of sexually transmitted diseases, a portrait of Leon Trotsky, and (controversially) a portion depicting Communism, containing a picture of Lenin, holding the hands of a worker, a soldier and a Black man. ${ }^{3}$ The picture of Lenin, showing him as the "worker-leader", upset both Rockefeller and the New York public in general. ${ }^{4}$ Rockefeller asked Rivera to change the face of Lenin to an unknown labourer's face, but Rivera refused. Rivera offered to paint in a picture of Abraham Lincoln to "balance" the mural, but this offer was rejected. Caught in an unyielding stalemate between patron and artist, Rockefeller paid for the work, but immediately covered it with cloth. It remained covered for a number of months and then, on 9 February 1934, workmen entered the Rockefeller building, destroyed the mural, and resurfaced the wall. ${ }^{5}$ Using photographs of the mural taken before it was destroyed, Rivera repainted it, albeit on a smaller scale. At present the work may be seen in the Palacio de Bellas Artes in Mexico City. ${ }^{6}$

South Africa today is by no means immune from the controversies which often surround the commissioning and protection of public art. This is well illustrated by the media row which erupted in February 2010, involving a large roadside sculpture of three life-sized elephants located in the city of Durban. The trouble started when the eThekwini Municipality commissioned an internationally acclaimed sculptor, Andries Botha, to conceptualize and construct a work of art to occupy an island in the middle of one of the main freeways leading into Durban, at what is known as the Warwick Triangle Junction. The sculpture, three massive elephants made of metal rods

\footnotetext{
According to http://www.phrases.org.uk/meanings/59100.html, accessed on 2011-02-15: "The person who is widely credited with coining the saying in its current form is Margaret Wolfe Hungerford (née Hamilton), who wrote many books, often under the pseudonym of 'The Duchess'. In Molly Bawn, 1878, there's the line 'Beauty is in the eye of the beholder' which is the earliest citation of it that I can find in print."

2 Scott "Diego Rivera at Rockefeller Center: Fresco Painting and Rhetoric"1977 41 Western Journal of Speech Communication 7073.

3 Ibid.

4 New York World-Telegram 24 April 1933 headlined "Rivera Paints Scenes of Communist/Activity and John D. Jr. Foots Bill."

5 Scott 197741 Western Journal of Speech Communication 75.

6 Scott 197741 Western Journal of Speech Communication 74.
} 
covered with stainless steel mesh filled with rocks and shown emerging from the soil, was commissioned at a cost of approximately R1,5 million. As work on the elephant sculpture was about to be completed in February 2010, Botha was instructed to stop work on the project. It was alleged in the media that the reason the order was given to stop work on the project, was because the elephants resembled the logo of the Inkatha Freedom Party, a political rival of the ruling African National Congress. ${ }^{7}$ The elephants in question became the focal point of a very public row between the sculptor and the eThekwini Municipality. Towards the end of 2010, in a surprising twist to the tale, it was reported in the media that the eThekwini Municipality had decided to destroy two of the three elephants, which would be replaced with other animals comprising the "big five". Apparently, this was regarded by city officials as a more "appropriate" symbol for the city. This proposal was, however, summarily rejected by the sculptor and, at the time of writing this article, the elephants in question remain mired in the mud behind a wall of shade cloth. ${ }^{8}$

Aside from all the political trouble caused by the elephants, this saga gives rise to a host of interesting legal and policy issues, and raises questions about how the modern, constitutional and democratic South Africa should respond to these tensions. It is the purpose of this article to examine certain of these issues and to interrogate the broad issue of public art, politics and the law in post-apartheid South Africa. It will be contended in the article that the elephants do not simply represent a point of intersection of various freeways, but that they represent a meeting point at which a number of competing stories, histories, philosophies and ideas of relevance to postapartheid South Africa collide. The elephants are, in a sense, symbolic of the current fault lines which fracture South African society. But not only do they represent a place of colliding narratives but, like billiard balls which collide and bounce off in different directions, they also represent a point of potentially new departures.

The central question to be addressed by this article is the following: In the context of post-apartheid South Africa, when public works of art are commissioned by public bodies, to what extent do state officials have the right to involve themselves and/or interfere in the process? In other words, in a constitutional democracy such as exists in South Africa at present, taking into account the values which underpin this society, to what extent may officials determine the nature of and/or interfere in the creation of a public work of art?

7 Van Wyk and Pillay "The Elephant that Caused all the Trouble" 18 February 2010 Mail and Guardian.

8 According to the 7 October 2010 Mail \& Guardian ("Elephant Artist Left in the Dark"): "An angry Botha said that Sutcliffe [the eThekwini City Manager] had approached him, asking if two of the three elephants could be removed and if Botha could produce four other sculptures, turning the piece into the big five. 'I wrote a letter to Mike Sutcliffe. I explained that I will not do the big five. I am not a tourist artist.' He said he was disappointed that the symbolism of the elephants - part of an internationally acclaimed series - had been trampled on by petty politics." 
The general debate concerning the desired relationship between public art, politics and the law is in its infancy in South Africa. The purpose of this article is not to solve all the specific legal issues which have arisen and are bound to arise in the future around this question. Instead, we hope to sketch certain of the general parameters - which are mandated by the values underpinning South Africa's constitutional democracy - within which we believe the general debate should take place. South Africa is a young constitutional democracy and, as pointed out above, it appears to us to be at something of an ideological crossroads at this time, making it particularly important that this debate be situated firmly within a sound framework of constitutional values. To some, debates around art, politics and the law may appear somewhat irrelevant, in light of the serious economic challenges facing so many South Africans at the present time. In our opinion, however, the soul of our new nation is intricately bound up with the vision of its artists. We submit, therefore, that there is much at stake in the outcome of this debate.

Apart from sketching the broad parameters of the general debate, we shall also point to certain of the specific legal issues arising out of the facts of the Durban elephant sculptures case. We shall do this not in order to second-guess what a future court hearing this matter might or might not decide, but in order simply to raise certain of the most salient legal issues which we believe courts dealing with such matters will need to address. When dealing with the specific legal issues which are potentially involved in such cases, we shall examine such issues both from the point of view of the artist involved, as well as from the point of view of the South African public. Distinct, but interrelated legal questions arise in relation to the potential rights of artists, as opposed to those of the South African public. The potential rights of artists in such scenarios may be sourced in a number of areas of the law - constitutional, contractual and statutory (the civil-law concept of "moral rights" having been introduced into the South African legal system by statute). As for the potential rights of the South African public in such scenarios, these may relate to the constitutionality of the commissioning process itself (that is, potential constitutional constraint on the actions of public officials who commission public works of art), as well as to the preservation of public works of art of "recognised stature". Before we embark on a discussion of legal specifics in the second part of this article, however, we shall use the first part of this article to set out what we believe to be the general parameters of the broad debate on public art, politics and the law in post-apartheid South Africa.

\section{A CLASH OF NARRATIVES}

As an initial step in tracing the competing narratives which eventually collide next to the freeway leading into Durban, let us begin with the story of the sculptor, Andries Botha, and the manner in which he became involved in sculpting elephants. The story of his involvement with elephants starts many years before the controversy described in the introduction. In 2006 Botha 
was asked to construct a major art work of his choosing to be exhibited in Belgium. Seeking inspiration, he decided to embark on a road trip into the heart of South Africa, and ended up in the middle of the Karoo, near Danielskuil, searching for rose quartz - "the Love Stone". Late one afternoon, he was speeding along in the direction of Springbok, when he passed a sign at the side of the road. The sign read: "Wonderwerkgrof" "Miracle Cave". Being an artist on a quest for inspiration, he decided to turn back and see where the sign led him. He drove up a farm road to a small museum of some kind. The caretaker was an Afrikaans-speaking man who appeared to be of Khoisan descent. ${ }^{9}$ The man led Botha into the Miracle Cave. Once inside, he took Botha by the hand. The further they progressed into the cave, the lower the roof became, and eventually they ended up kneeling in one corner of the cave. The man then pointed to a small rock painting on the wall of the cave. It was a Khoisan painting of a small elephant. The man turned to Botha and said: "Kyk hier, dis 'n oliefant, kan jy dit glo. Is hy nie wonderlik nie?" - "Look here, it's an elephant, can you believe it. Is he not beautiful?" This, for Andries Botha, is where the story of the elephants started.

Inspired by the Khoisan rock art, Botha decided to make a series of lifesized elephants for his exhibition in Belgium. Obviously, from an artistic perspective, the image of the elephant is full of resonance in the context of the intertwined histories of Africa and Belgium. Belgium's colonial rule in the Congo was notorious for its brutality. Thousands upon thousands of elephants were shot out by the colonizers in their seemingly insatiable quest for ivory. ${ }^{10}$ Now Botha planned to return some elephants from Africa to Belgium as a gentle reminder, perhaps, of this history. But these elephants would have an additional message for Europe and the world. This message would be related to the current environmental crisis facing humanity. The elephant would act as a sort of messenger, with a warning for humankind that we need to discover an entirely different way of relating to the natural world, or else face ecological disaster. ${ }^{11}$ And so he made a number of

9 The Khoisan are the original inhabitants of Southern Africa, the people who have inhabited this land for around 120,000 years, the symbolism of which was not lost on Botha.

10 So highly did the Belgians value ivory, it has been said that "[t]he annexation of the Congo to Belgium was the beginning of a new form of exploitation. Indeed, ... ivory became one of the main currencies in achieving this goal, in lieu of such mineral resources as gold". See Kisangani $A$ Social Dilemma in a Less Developed Country: The Massacre of the African Elephant in Zaire in Proceedings of the Conference on Common property Resource Management: 1985, National Research Council (Washington) 147.

11 Clearly, there are deep philosophical roots underlying initiatives of this kind. The spiritual father of what has come to be known as the "deep ecology movement", the Norwegian professor of philosophy, Arne Naess (who died on 12 January 2009), would probably have applauded Botha's project. In explaining one of the central principles upon which the philosophy of "deep ecology" is based, an "ethos of biospherical egalitarianism", Naess states as follows: "To the ecological field-worker, the equal right to live and blossom is an intuitively clear and obvious value axiom. Its restriction to humans is an anthropocentrism with detrimental effects upon the life quality of humans themselves. This quality depends in part upon the deep pleasure and satisfaction we receive from close partnership with other forms of life. The attempt to ignore our dependence and to establish a master-slave role has contributed to the alienation of man from himself." See Naess "The Shallow and the Deep, 
massive elephants and shipped them to Belgium. The plan was to place them on a beach, walking up out of the sea, as if they had strolled across from Africa. When he got to Belgium, however, he found the beach on which the elephants were to be exhibited to be cold and grey, and so he decided that his elephants would be positioned in such a way that they were walking away from Europe, back towards their African homeland. He placed his massive elephant sculptures walking in line into the waves, with two of them partly submerged at high tide. The exhibition turned out to be a resounding success and the elephants subsequently went on tour to various parts of Belgium.

During subsequent years, a range of other elephant sculptures were constructed by Andries Botha. Some of these followed the example of the Belgian elephants and started touring the world. Botha became internationally known for this work. ${ }^{12}$ Along the way he established the Human Elephant Foundation with well-known South African conservationist $\mathrm{Dr}$ lan Player. ${ }^{13}$ It was at this stage that the narrative of Andries Botha and the elephants took the rather bizarre turn related in the introduction to this article. Botha was asked by the eThekwini Municipality to do a sculpture for the Warwick Triangle area. ${ }^{14} \mathrm{He}$ decided to make three large elephants out of metal rods covered with stainless steel mesh and filled with rocks, which were to be shown emerging from the earth. These elephants were to form part of a larger grouping of elephants, which would have been placed at intervals in various parts of the city leading to the beach. This procession of elephants would have echoed the original elephant sculpture which Botha had erected on the beach in Belgium years before. Botha regarded these elephants as a powerful symbol of the natural world, and man's fractured relationship with that world. As work on the Warwick Triangle elephants was coming to an end, he was ordered off site and the project was frozen.

Long-Range Ecology Movement - A Summary" 197316 Inquiry 95-100, reproduced in Baird Callicott and Palmer (eds) Environmental Philosophy - Critical Concepts in the Environment - Volume II (2005) 5152.

12 At the time of writing the present article, there is a giant Botha elephant made of wire mesh woven with rubber from recycled motor car tyres touring the United States.

13 The aim of this organization is to raise awareness of the troubled relationship between man and nature, and the urgent need for humans to seek a less destructive way of relating to the natural world. The website of the Human Elephant Foundation quotes Andries Botha as follows: "The elephant is a metaphor for the yearning for forgotten conversations between humans, the Earth and all living things." See http://www.humanelephant.org/ accessed February 2011.

14 According to certain reports in the media, the last wild elephants in the Durban region were said to have been shot near this area. On this point it is interesting to note the following recent comments by Skinner and Chimimba: "In Kwa-Zulu Natal the bush around the present-day suburb of Berea in Durban was noted for its large elephant population. Traces of elephant paths, numerous in the 1860s, were still discernable in the 1880s. Between 1850 and 1875 immense numbers of elephants were destroyed in what was then Natal. In $1873, £ 17199$ worth of ivory was exported through Natal and in 1885 this had declined to $£ 4$ 100. The last elephants were shot at the Umgeni River in 1854, but there seems little doubt that there continued to be movements into northern KwaZulu-Natal from southern Mozambique that have continued up to the present day (Klingenhoefer, 1987)." (References removed.) See Skinner and Chimimba The Mammals of the Southern African Subregion (2005) 54 . 
As for the competing narratives in this case, there were vague reports in the media that the objection of the municipality to the elephants was that they resembled the logo of the Inkatha Freedom Party. ${ }^{5}$ A newspaper report, about a week after the event, reported the incident as follows:

"On February 9, Botha said he received a phone call from Siya Madlala and S'bu Mazibuko, two former students who were assisting him with the artwork, saying that they had been ordered to stop work immediately by a man who refused to identify himself. The man, driving a large black SUV, apparently told them that the elephants were a symbol of the IFP, and were therefore not welcome in a city run by the ANC."

Another newspaper article stated that it was "ANC leaders, apparently led by the late eThekwini region chairman John Mchunu" who had insisted that the artwork in question could not represent the municipality, since the insignia of the Inkatha Freedom Party consisted of three elephants. ${ }^{17}$

For their part, the Inkatha Freedom Party condemned the whole affair as "a fruitless waste of money". ${ }^{18}$ On 9 November 2010, perhaps sensing a golden opportunity to score political points, the IFP issued a media statement entitled "Give Elephant to Us", in which it was revealed that the Chairperson of the IFP Municipal Caucus had urged the Durban Municipal Manger to consider giving one of the three controversial elephants to the IFP instead of destroying it, in order to avoid a "waste of resources and energy". The Inkatha Freedom Party offered to display the elephant at its Offices in Ulundi, and stated that acceptance by the Municipal Manager of the party's request would be "a humane gesture which would make a contribution to the on-going efforts at improving relations between the IFP and ANC". ${ }^{19}$ This offer was rejected outright by the ANC. In his reply, the eThekwini Municipal Speaker, James Nxumalo, stated as follows:

"My office has received the letter from the IFP caucus leader Councillor Mdu Nkowi, requesting the municipality to donate one of the elephants in Warwick Triangle to the party. Council has a resolution on the matter and we are still

15 See in this regard: "Jumbo Art a White Elephant" (2010-02-15) http://www.iol.co.za/news/ politics/jumbo-art-a-white-elephant-1.473501.

16 Van Wyk and Pillay 18 February 2010 Mail \& Guardian. See too the article "Botha's Elephants' Fate Still Undecided" March 2010 South African Art Times in which it was stated: "It has now been widely reported that Botha's team was told to cease construction several weeks ago after a man in a black SUV stopped on the freeway, where the sculptures were being built from stone and steel gabions, and ordered that the work be halted - apparently because the elephants are a symbol of the IFP and Durban is an ANC city. That man was identified by the workers as John Mchunu, regional chairperson of the ANC, although Mchunu has reportedly denied this."

17 Makhanya "Politics is a Collective Lunacy in South Africa - Ask the Elephants" 21 November 2010 The Times.

18 One newspaper report summed up the views of the IFP as follows: "Thembi Nzuza, leader of the IFP caucus in eThekwini council, said the brouhaha surrounding the elephant sculptures was 'ridiculous and childish' ... 'We, as the IFP, are actually taking offence by the municipality's behaviour - the elephant goes beyond the IFP and is part of greater South Africa. Where will all this end: The DA uses the sun on its logo, so will the ANC next try and stop the sun from rising?" See Van Wyk and Pillay 18 February 2010 Mail \& Guardian.

19 Nkosi "Give Elephant to Us" 9 November 2010 Media Statement of the Inkhata Freedom Party. 
awaiting a report by the city manager on the way forward ... We totally reject the IFP's attempt to politicise this matter. We cannot donate any of the elephants to a political party as we would be politicising the work of the artist."

The apparent political point-scoring between the African National Congress and the Inkatha Freedom Party in relation to this issue must be seen in light of the long history of antagonism between these two political parties. The history of violence between followers of the Inkatha Freedom Party and the African National Congress, particularly during the 1980s and early 1990 s is, of course, well known. ${ }^{21}$ For the purposes of this article, it is clear that the Durban elephants mean different things to different people. Certainly, they symbolize something completely different to those who ordered work on the project to be stopped, than they do to the artist Andries Botha. With further information on this developing controversy in short supply, it is worthwhile at this point to look back into South Africa's history in an effort to shed light on the fault lines which have emerged around the issue of art and its place in this country. These fault lines have deep roots which need to be unearthed in order to understand properly contemporary controversies surrounding public art, politics and the law in post-apartheid South Africa.

\section{HISTORICAL AND IDEOLOGICAL ROOTS}

Evidence of a clash of narratives on the question of the proper role of art and artists in South Africa goes back at least two decades to the dawn of democracy in this country. In 1990, as South Africa began to emerge slowly from the stultifying grip of the apartheid system, the question of art and its role in the traumatised country came to the fore. The question was raised by Albie Sachs, at that time a member of the National Executive Council of the ANC. In a paper entitled "Preparing Ourselves for Freedom", Sachs challenged his comrades to begin conceptualizing art and its place within a changing South Africa, in a way which transcended the idea - generally accepted within the liberation movement at the time - that art was, first and foremost, a weapon of the liberation struggle. Lamenting the lack of works

20 Cllr James Nxumalo 12 November 2010 Press release: Response to IFP Statement on Elephants.

21 The tension between the ANC and the IFP can be traced back to the defection of Buthelezi from the ANC Youth League in 1975, when he founded the Inkatha Freedom Party (originally known as the Inkatha National Cultural Liberation Movement) in what is now KwaZulu-Natal. The party was born out of the cultural movement "Inkhata" (Zulu for "crown"), formed by King Solomon Dinuzulu in 1928. Although the ANC and IFP parties were originally very close and supported each other in the struggle against apartheid, relations soon faltered to such an extent that the ANC/IFP rivalry has been described as a "bitter and sporadically intense low-level civil war". The increasingly violent clashes (often in "street battles") between the ANC and the IFP meant that the 1990s saw a real threat of civil war in South Africa, with declared "no go" zones for members of both parties. Strong political differences emerged in relation to the Zulu King (whom the IFP wanted as Head of State and the predominately-Xhosa ANC resisted) and the model of governance, in which the IFP emerged as champion of maximum regional autonomy, and the ANC of a central state (see, eg, Christie Ethnic Conflict, Tribal Politics: A Global Perspective (1998)). 
within the revolutionary struggle-art of the time dealing with the subject matter of love, Sachs challenged the broad liberation movement as follows:

"And what about love? We have published so many anthologies and journals and occasional poems and stories, and the number that deal with love do not make the fingers of a hand. Can it be that once we join the ANC we do not make love any more, that when the comrades go to bed they discuss the role of the white working class? Surely even those comrades whose tasks deny them the opportunity and direct possibilities of love, remember past love and dream of love to come. What are we fighting for, if not the right to express our humanity in all its forms, including our sense of fun and capacity for love and tenderness and our appreciation of the beauty of the world."

Sachs's paper caused significant controversy within the ANC at the time, with the Transvaal Interim Cultural Desk of the ANC responding as follows:

"We challenge cultural workers to root themselves in the democratic movement so that their creative responses to life will be informed by an understanding and experience of the struggle. We thereby reiterate the view of the Gaberone and CASA (Culture in Another South Africa) conferences on culture that one is first part of the struggle and then a cultural worker."

This, perhaps, takes us to the nub of the problem. We have two competing and seemingly irreconcilable world-views. These world-views determine, to a large extent, the manner in which one answers certain fundamental questions which are crucial to the outcome of the broad debate on the proper relationship between art, politics and the law within a constitutional democracy. Most fundamental is the question "What is art?" which is closely followed by the question "What is the role of art in society?" Simply put, we may, perhaps, counterpoise a broadly neo-Marxist view of art, with a broadly liberal view. From the former viewpoint, perhaps according with that of the Cultural Desk above, the artist's duty to the "struggle" comes before whatever duty he or she may have to "art". Art is necessarily political. The artist is a political actor, occupying a particular class position and situated at a particular historical conjuncture, and is not simply a neutral observer or commentator. During the liberation struggle in South Africa, every word in every poem was a bullet. ${ }^{24}$ Those engaged in the struggle did not enjoy the luxury of engaging in art for art's sake.

22 Albie Sachs "Preparing Ourselves for Freedom" in De Kok and Press (eds) Spring is Rebellious - Arguments about Cultural Freedom by Albie Sachs and Respondents (1990) 20-21. The title of the present article is a play on the title of this book.

23 Transvaal Interim Cultural Desk "The Cultural Boycott and Albie Sachs' Paper" in De Kok and Press (eds) Spring is Rebellious - Arguments about Cultural Freedom by Albie Sachs and Respondents (1990) 107-108.

24 Eg, Krylov states as follows in the preface to Marx and Engels on Literature and Art: "The founders of Marxism emphasised that art was an important weapon in the ideological struggle between classes. It could reinforce just as it could undermine the power of the exploiters, could serve to defend class oppression or, on the contrary, contribute to the education and development of the consciousness of the toiling masses, bringing them closer to victory over their oppressors. Marx and Engels therefore called for a clear distinction to be made between progressive and reactionary phenomena in feudal and bourgeois culture and put forward the principle of the Party approach to art that it be evaluated from the position of the revolutionary class." See Marx and Engels Marx and 
From the liberal perspective, on the other hand, there is a much greater focus on the individual and on individual autonomy - and the creation of art for art's sake. The liberal tradition is centrally concerned with defining and protecting the right of each individual in a democratic society to define his or her own conception of what constitutes a good life, and to live his or her life accordingly, without undue interference. It is very important to liberal thinkers that this individual freedom, the space for individuals to decide upon and live out their own particular conceptions of the good, be jealously guarded against inroads due to societal pressures. According to John Stuart Mill, a foundational thinker within the liberal tradition:

"The only freedom which deserves the name, is that of pursuing our own good in our own way, so long as we do not attempt to deprive others of theirs, or impede their efforts to obtain it. Each is the proper guardian of his own health, whether bodily, or mental or spiritual. Mankind are greater gainers by suffering each other to live as seems good to themselves, than by compelling each to live as seems good to the rest."

For liberals, it is important to maintain a strict separation between "the public" and "the private", and to ensure that an inviolate sphere of privacy surrounds and protects each individual. ${ }^{27}$ The freedom of individuals to decide upon and pursue their own conceptions of the good is sacrosanct to liberal thinkers. To liberals, any attempt to interfere with the freedom of South Africans to make their own moral and aesthetic choices would be anathema.

It may be argued, perhaps, that more than a decade and a half after the end of apartheid, South Africans have still not quite decided upon which of the abovementioned two world-views to adopt. Furthermore, if it is correct that South Africa remains an ideologically fractured society, unable to

Engels on Literature and Art (1976) Progress Publishers: Moscow as transcribed by Andy Blunden at http://www.marxists.org/archive/marx/works/subject/art/preface.htm accessed 2011-02-15.

25 Note, eg, the following comment of Krylov in the preface to Marx and Engels on Literature and Art: "Marx and Engels were highly critical of attempts to place literature above politics and of the theory of 'art for art's sake'. They insisted that the works of realist writers should reflect a progressive world outlook, be permeated with progressive ideas and deal with truly topical problems." See Marx and Engels in fn 24 above.

26 Mill On Liberty (1859) Chapter 1 par 13.

27 This idea is, perhaps, most famously expressed in what has become known as Mill's "harm principle", which he sets out as follows: "[T]he sole end for which mankind are warranted, individually or collectively in interfering with the liberty of action of any of their number, is self-protection ... [T] he only purpose for which power can be rightfully exercised over any member of a civilized community, against his will, is to prevent harm to others. His own good, either physical or moral, is not a sufficient warrant. He cannot rightfully be compelled to do or forbear because it will be better for him to do so, because it will make him happier, because, in the opinions of others, to do so would be wise, or even right. These are good reasons for remonstrating with him, or reasoning with him, or persuading him, or entreating him, but not for compelling him, or visiting him with any evil, in case he do otherwise. To justify that, the conduct from which it is desired to deter him must be calculated to produce evil to some one else. The only part of the conduct of any one, for which he is amenable to society, is that which concerns others. In the part which merely concerns himself, his independence is, of right, absolute. Over himself, over his own body and mind, the individual is sovereign." See Mill par 9 . We shall return to this principle below. 
overcome the divisions of its past, this may explain why Andries Botha's elephants have become stuck in the mud in Durban. The elephants remain in legal, political and ideological limbo, a powerful symbol of the uncertainty which characterizes South African society as a whole. Having sketched the broad political and ideological background to the issues under examination in this article, let us proceed to a discussion of the constitutional values which we believe are crucial to setting the parameters of the debate on the proper relationship between art, politics and the law in South Africa today. In particular, we wish to focus on the role of public art within a liberal constitutional democracy.

\section{4}

\section{PUBLIC ART IN A LIBERAL CONSTITUTIONAL DEMOCRACY}

It is submitted that a crucial factor to be considered in cases involving publicly funded or commissioned works of art, is that these works are purchased with public funds, as opposed to the personal funds of a private patron. In this context, the question of the precise nature of the public sphere, and its relationship to public art, comes to the fore. We submit that South Africa is a country which is still involved in a process of national dialogue over values relating to many areas of life, including the "proper" relationship to be maintained between state officials and public art. In order to arrive at an understanding of the constitutional values at stake, we propose to address the following fundamental questions: "Precisely what sort of constitutional democracy is South Africa?", and "Is it desirable or, indeed, mandatory for those in charge of such a constitutional democracy to fund public art?", and "If so, what should be the ground rules for funding public art in such a constitutional democracy?"

Let us begin with the first of these "big questions": that is, "Precisely what sort of constitutional democracy is South Africa?" It is submitted that a strong argument may be put forward to the effect that, at least in relation to the issues of tolerance and diversity, South Africa is or should aspire to be liberal in nature. It may be argued that tolerance of diversity is one of the central pillars of South Africa's democracy. After all, the preamble to the South African Constitution speaks of South Africans as people "united in our diversity" who are seeking to: "Lay the foundations for a democratic and open society ..." South Africa is a nation which recognizes and constitutionally protects eleven official languages, and whose national flag contains no fewer than six colours. The South African national anthem is sung to two conjoined but completely different tunes, and in four different languages. All this indicates that tolerance of diversity is central to South Africa's constitutional democracy. ${ }^{28}$ Furthermore, the South African

28 Some years before the end of apartheid, Sachs (24), one of the architects of South Africa's democracy, stated as follows: "We believe in a single South Africa with a single set of governmental institutions, and we work towards a common loyalty and patriotism. Yet this is not to call for a homogenised South Africa made up of identikit citizens. South Africa is now said to be a bilingual country: we envisage it as a multi-lingual country. It will be multi-faith 
Constitutional Court has confirmed the importance of this principle on numerous occasions. Of all the judges of the Constitutional Court, it may be argued that the jurist who has stood up for the centrality of this principle more strongly than any other, is Justice Albie Sachs. ${ }^{29}$ Take, for example, his judgment in the well-known Prince case, in which he states as follows: "Given our dictatorial past in which those in power sought incessantly to command the behaviour, beliefs and taste of all in society, it is no accident that the right to be different has emerged as one of the most treasured aspects of our new constitutional order." ${ }^{30}$ In the case of Christian Education South Africa $v$ Minister of Education he points out that "if society is to be open and democratic in the fullest sense it needs to be tolerant and accepting of cultural pluralism". ${ }^{31}$ Furthermore, he refers to the "constitutional value of acknowledging diversity and pluralism in our society" and goes on to affirm "the right of people to be who they are without being forced to subordinate themselves to the cultural and religious norms of others", as well as "the importance of individuals and communities being able to enjoy what has been called the 'right to be different"'. ${ }^{32}$ In the Fourie case, he provides the following eloquent and moving exposition as to why tolerance and respect for diversity is so important within the context of South Africa's present constitutional democracy:

"Equality ... does not imply a levelling or homogenisation of behaviour or extolling one form as supreme, and another as inferior, but an acknowledgement and acceptance of difference. At the very least, it affirms that difference should not be the basis for exclusion, marginalisation and stigma. At best, it celebrates the vitality that difference brings to any society. The issue goes well beyond assumptions of heterosexual exclusivity, a source of contention in the present case. The acknowledgement and acceptance of difference is particularly important in our country where for centuries group membership based on supposed biological characteristics such as skin colour has been the express basis of advantage and disadvantage. South Africans come in all shapes and sizes. The development of an active rather than a purely formal sense of enjoying a common citizenship depends on recognising and accepting people with all their differences, as they are. The Constitution thus acknowledges the variability of human beings (genetic and sociocultural), affirms the right to be different, and celebrates the diversity of the nation. Accordingly, what is at stake is not simply a question of removing an injustice experienced by a particular section of the community. At issue is a need to affirm the very character of our society as one based on tolerance and mutual respect. The test of tolerance is not how one finds space for people

and multi-cultural as well. The objective is not to create a model culture into which everyone has to assimilate, but to acknowledge and take pride in the cultural variety of our people."

29 Sachs himself states as follows in his book The Free Diary of Albie Sachs (2004) 67-68: "I have gone further than any of my colleagues in emphasizing that the Constitution calls for the widest recognition of openness, difference and pluralism ... It is easy to tolerate beliefs and practices that are familiar and enjoy strong political support. The true test of tolerance comes when the practices exist on the margins of society and appear bizarre, even threatening to the mainstream."

30 Prince $v$ President of the Law Society, Cape of Good Hope 20022 SA 794 (CC) par 170. In the context of a discussion about art, it is submitted that the words "and taste" in this quotation are particularly relevant.

31 Christian Education South Africa v Minister of Education 20004 SA 757 (CC) par 23.

32 Christian Education South Africa v Minister of Education supra par 24. 
with whom, and practices with which, one feels comfortable, but how one accommodates the expression of what is discomfiting."

The above all points to South Africa being a constitutional democracy in which one of the central pillars is the liberal principal of tolerance of diversity.

This brings us to the second of the "big questions" set out above: that is, "Is it desirable or, indeed, mandatory for those in charge of such a constitutional democracy to fund public art?" We may begin to answer this question by referring to the work of the natural law philosopher, John Finnis. According to Finnis, aesthetic experience is one of only seven basic human goods. It may be argued that if our law is to be regarded as "focal law", that is, law which promotes the human good, it is obliged to promote art, precisely for the reason that art is not an "optional extra" but is in fact "spiritual food" for human beings, which is fundamental to our well-being that is, it is intimately related to the human good. ${ }^{34}$ For a somewhat less "lofty" approach, we may consider the work of the well-known legal philosopher Ronald Dworkin, who deals with this particular question in an essay entitled: Can a Liberal State Support Art ${ }^{35}$ Dworkin argues that public art is a kind of public good, much like the military, law enforcement, lighthouses, road infrastructure and streetlights, which a society cannot provide for itself by means of the free-market system. ${ }^{36}$ The public good to which Dworkin is referring is not necessarily to be found within the appreciation of art itself. Dworkin recognizes that there are certain forms of art from which few people in society derive a benefit. Rather, the "good" to which he is referring is the very structure of the intellectual culture in which we live. Dworkin explains as follows:

"The choice between art and the rest is not the choice between luxury and necessity, grandeur and duty. We inherited a cultural structure, and we have some duty, out of simple justice, to leave that structure at least as rich as we found it."

Under this argument, then, art qualifies for subsidy in a liberal society. It is important to note, however, that it must be art in general which is promoted, rather than a restricted category of art which, at a particular time, happens to carry some or other official stamp of approval. In Dworkin's words:

33 Minister of Home Affairs vs Fourie 20061 SA 524 (CC) par 60. Further on in his judgment, in terms which may be said to be distinctly reminiscent of the thinking of Mill and Dworkin, Sachs $\mathrm{J}$ drives home the basic point made in the section quoted, when he states as follows (par 95): "The hallmark of an open and democratic society is its capacity to accommodate and manage difference of intensely-held world views and lifestyles in a reasonable and fair manner. The objective of the Constitution is to allow different concepts about the nature of human existence to inhabit the same public realm, and to do so in a manner that is not mutually destructive and that at the same time enables government to function in a way that shows equal concern and respect for all."

Finnis Natural Law and Natural Rights (1980) 18.

35 Dworkin "Can a Liberal State Support Art?" Chapter 11 in A Matter of Priniciple (1985).

36 A public good is, in economic terms, a good which is non-rival (in that the fact that one person uses it does not mean that there will be less for the next person to enjoy), and nonexcludable (in that no one can be excluded from using or enjoying the good).

37 Dworkin 233. 
"So the ruling star of state subsidy should be this goal: it should look to the diversity and innovative quality of the culture as a whole rather than to (what public officials take to be) excellence in particular occasions of that culture.,38

Let us now move on to the final of the "big questions" set out at the start of this section: that is, "What should be the ground rules for funding public art in a constitutional democracy such as that in South Africa?" If, as has been argued above, it is liberal values such as tolerance, openness and diversity which should be central in guiding South Africa's democracy, then these values should also shape state policy in relation to the funding, commissioning, and general response to, art. Public art, commissioned or funded by the state, is one way in which the beautiful diversity of the South African nation may be expressed and nurtured. South Africa does not need the top-down, univalent form of public art which characterized the totalitarian dictatorships of the twentieth century, such as Hitler's Germany or Stalin's Soviet Union. It needs multivalent public art which expresses the full diversity of the South African people. To facilitate this, it is imperative that the state adopt a "hands-off" and "arms-length" approach when it comes to funding or commissioning public art. Indeed, there were promising signs when the White Paper on Arts and Culture was drawn up in 1996. The then Minister of Arts and Culture, Dr Ben Ngubane, stated in his introduction to the paper as follows:

"The role of the State in funding arts, culture and heritage is a complex one. In some countries, no State support is forthcoming; in others the State plays a decisive role. We must be attuned to our own particular situation, and wish to develop exactly that 'arms length' relationship which is fundamental to freedom of expression. At the same time, all funding from the public purse carries certain obligations with it, and these obligations of accountability must be applied with due responsibility and creativity. Promotion without undue promulgation would be our ideal."

It is submitted that the "arms length" relationship described by the former Minister as "fundamental to freedom of expression", is exactly what Ronald Dworkin had in mind when he insisted that it is "the diversity and innovative quality of the culture as a whole" which must be supported by the State, rather than a particular form of that expression, having a particular content. ${ }^{40}$ Further, it is submitted that the quotation set out above accurately expresses the balancing act which the state needs to perform in relation to the funding and commissioning of art in a constitutional democracy such as that adopted by South Africa in 1994. The problem, however, is that it is difficult to reconcile the former Minister's sentiments set out above, with the approach that seems to have been adopted by local politicians in Durban, which has given rise to the present "elephant trouble" in that city. If it is correct that tolerance of diversity and openness are cornerstones of South Africa's present democracy, then what is needed is public art which is edgy,

\footnotetext{
Ibid.

39 Department of Arts, Culture, Science and Technology (4 June 1996) White Paper on Arts, Culture and Heritage, Government Printers, Pretoria.

40 See the statement by Dworkin quoted above.
} 
challenging and above all diverse, not public art which is hidden from view behind a wall of shade cloth.

\section{THE LIMITS OF FREE ARTISTIC EXPRESSION}

The argument set out above should not be taken to mean that the state must never interfere with the work of an artist which it has commissioned or funded. Public money should not be used to fund art work which causes harm or serious offence. Of course, determining what constitutes "harm" or "serious offence" is not necessarily a simple task. Mill famously argued that "the only purpose for which power can be rightfully exercised over any member of a civilized community, against his will, is to prevent harm to others". ${ }^{41}$ Joel Feinberg, in turn, argued that Mill's harm principle set the standard for government interference too high, and that the principle did not go far enough to protect society against offensive (though not necessarily harmful) conduct. In addition to the harm principle, Feinberg proposed what has become known as the offense principle, which is able to act as a guide to public censure. He states (with reference to the ambit of criminal law regulating offensive conduct) that "[i]t is always a good reason in support of a proposed criminal prohibition that it is probably necessary to prevent serious offense to persons other than the actor and would probably be an effective means to that end if enacted". ${ }^{42}$ We argue that a similar set of principles to those outlined by Mill and Feinberg could, perhaps, be used to determine those situations in which it is legitimate for the state to censor artistic expression. Combining and rephrasing the harm and offence principles discussed above, we tentatively propose the following formulation: Within a constitutional democracy such as that which exists in post-apartheid South Africa, the only purposes for which state power may be exercised legitimately to censor art are: either to prevent harm ${ }^{43}$ or to prevent serious offence to those falling under the protection of the South African Constitution. ${ }^{44}$

It is submitted that the harm and offence principles discussed above do not end the matter. Apart from works of art which cause harm or serious offence it may be argued, perhaps, that public money which has been allocated for the procurement of public art should not be used to fund work which is patently not art. This article cannot hope to meaningfully address

1 Mill On Liberty (1978).

42 Feinberg The Moral Limits of the Criminal Law, Volume Two: Offense to Others (1985) 26. "Offense" for Feinberg consists of both subjective and objective elements: the subjective element may involve personal feelings of shame, disgust, anxiety or embarrassment, affronts to sense or sensibility, shock, humiliation or fear, whereas the objective element requires the existence of a wrongful cause for the mental state in question. Feinberg considers that offence is less serious than harm, and that punishment for offensive conduct should be less severe than punishment for conduct which causes actual harm.

43 This version of the harm principle would cover, for example, hate speech designed to incite violence, and art constituting propaganda.

44 This version of the offence principle would cover, for example, certain kinds of pornography, as well as art which constitutes "serious offence" to certain religious or racial groups. 
the philosophically complex and intricate question: "What is art?" (a question with which philosophers such as Kant, ${ }^{45}$ Heidegger, ${ }^{46}$ and Plato, ${ }^{47}$ to name but a few, have grappled). Perhaps, however, an extreme example may serve to illustrate the point we are trying to make: Imagine a vast commission, worth millions of rands, is available. It is awarded, via a government tender process, to an unknown "artist", who uses it to build a simple brick wall in the allocated public space. The construction takes a group of labourers one afternoon, and each is paid half a day's wage. The artist appears briefly on site to supervise the process. The wall is neither high nor impressive; it is simply a moderately well-made, entirely useless, not very beautiful collection of bricks. The total cost of the piece runs to a few hundred rands. The "artist" pockets the rest of the millions.

While none of the factors presented above (the extent of the artist's participation in the creation of the artwork, the small cost of the production of the piece relative to the grant, the lack of beauty in the work, and the mundaneness of the subject matter, to name but a few) could, on its own, be determinative of whether or not the work is "art", taken together, few could argue (we submit) that public art money could legitimately be used to fund work of this sort. And the reason: the simple recognition by the overwhelming majority of people that what is produced with the money is not art. Of course, these lines are extremely difficult to draw in practice. ${ }^{48}$ Richard Posner laments the fact that

"While it is possible to make objective measurements of physical properties such as weight and speed, it is not possible to make such measurements of artistic value, because of people having different values and preferences do not agree and cannot be brought to agree on how to determine the presence of that attribute or even how to define it.

There seems to be no easy "short-cut solution" in deciding whether something is "art" and it is submitted that our courts will have to examine

45 Kant Critique of Judgement (1790) trans Meredith (1997).

46 Heidegger "The Origin of the Work of Art" (1960) in trans Hofstadeter Poetry, Language, Thought (1975).

47 Plato The Republic (-360) trans Lee (1979).

48 We are well aware, eg, of the controversy engendered by the work entitled "Equivalent VIII" by the minimalist artist Carl Andre, which was purchased by the Tate Gallery, London, in 1972 and which consists of 120 firebricks arranged in a simple rectangular formation. It is considered to be an important minimalist work, but created a public uproar. See http://www.tate.org.uk/archivejourneys/historyhtml/people_public.htm accessed April 2011. We may also cite the example of John Cage's famous 1952 musical composition "4'33", possibly one of the most controversial compositions of the $21^{\text {st }}$ Century. In 4 '33, the three movements are "performed" by a pianist on stage, yet not a single note is played. The content of the composition is silence, and the audience is encouraged to listen to and appreciate the ambient sounds of the environment in which the "performance" takes place. In an address given to the Convention of the Music Teachers National Association, Chicago in 1957, entitled "Experimental Music", Cage said of his work: "There is no such thing as an empty space or an empty time. There is always something to see, something to hear." See Solomon "The Sounds of Silence: John Cage and 4'33" http://solomonsmusic.net/ 4min33se.htm accessed April 2011.

49 Posner "Art for Law's Sake" 198958 The American Scholar 513514. 
each such case on its own merits. This is not to say, however, that our courts should ignore broad constraining principles such as those we have sketched above.

\section{LESSONS FROM ABROAD}

In the sections set out above, we have attempted to locate the debate around the desired limits to interference by state officials in public art, within the general historical, ideological, political and constitutional context of postapartheid South Africa. We believe that the specific legal questions which arise in particular situations of this kind, such as that facing Andries Botha in Durban at the time this article is being written, will need to be confronted by our courts within this general context. However, in order to finalize part one of this article dealing with the general parameters of the debate in question, we need to take account of a further set of factors which may serve to influence the debate in this country. Certain jurisdictions in other parts of the world possess a much richer legal jurisprudence on issues related to the commissioning and funding of art by state bodies than South Africa. We believe it is useful to end off part one of this article by providing a brief overview of certain of the more prominent North American cases dealing with such issues, in order to complete the picture we have attempted to sketch, setting out the broad parameters of this debate.

The prominent American academic Frederick Shauer ${ }^{50}$ has described the difficulty facing courts in determining such issues as follows:

"Indeed, if there is a difference between the state hiring a librarian to select only books expressing the state's viewpoint or hiring a university professor to argue the state's viewpoint, on the one hand, and the state hiring an artist to paint a mural on a state office building including George Washington but not Vladimir Lenin, on the other ... the task is to identify when the state can use its power over its employees or contractors to conscript them into service as the state's voice. This is a real and important question ....

We submit that one potentially useful distinction to be gleaned from the North American case law (which seems to be particularly rich in this area), is between those situations in which a state body has actively commissioned a public work of art, and those in which it has simply funded an independent institution, such as a museum, which then commissions the work. In the latter situation, it appears that the American courts regard any attempted state interference with the art work with great circumspection. Even if the state body concerned maintains that the art work is harmful, or greatly offensive, or simply not art, there is often suspicion that the reasons provided are a smokescreen, which is hiding a political motive on the part of that state body. In the former situation (that is, where a state body actively commissions a specific work of art), the American courts seem to allow the

50 The Frank Stanton Professor of the First Amendment at the John F Kennedy School of Government, Harvard University.

51 Schauer "Principles, Institutions and the First Amendment" 1998112 Harvard LR 84. 
state body concerned a greater "margin of appreciation" to intervene, although by no means do they allow state officials carte blanche to interfere as they wish.

The case of The Brooklyn Institute of Arts and Sciences vs The City of New York and Rudolph Giuliani ${ }^{52}$ seems to illustrate the broad approach of the American courts to those situations in which a state body funds an independent institution, such as a museum, which then commissions a work of art which a state official finds objectionable (that is, the "latter situation" sketched above). In this case the erstwhile Mayor of New York (Rudolph Giuliani) attended the Brooklyn Museum's temporary exhibit entitled "Sensation: Young British Artists from the Saatchi Collection". Appalled by the content of the exhibition, Giuliani publicly denounced it as "sick" and "disgusting", with a particular objection raised against one painting, The Holy Virgin by artist Chris Olifi, on the ground that it was offensive to Catholics and constituted an attack on religion. Giuliani famously declared:

"You don't have a right to a government subsidy to desecrate someone else's religion. And therefore we will do everything that we can to remove funding from the [Museum] until the Director comes to his senses, and realizes that if you are a government subsidized enterprise then you can't do things that desecrate the most personal and deeply held views of the people in society."

Thereafter, the City withheld funds already appropriated to the Museum for operating expenses, and sought to eject the Museum from the city-owned land and building in which it had been housed for over 100 years, despite the fact that the Brooklyn Museum houses one of the largest and most impressive collections in the United States. ${ }^{54}$ The work in question (The Holy Virgin) was part of a series of five very colourful canvases incorporating paper collage, coloured drawing pins, foil, paint, glitter and elephant manure. It depicted the Virgin Mary, ornately decorated, with a piece of elephant manure on the side of her right cheek. ${ }^{55}$

Following the withdrawal of funding, the Museum launched an action for declaratory relief, preventing the City from punishing it or retaliating against the exhibit, in violation of the Museum's rights under the First and Fourteenth Amendments to the American Constitution. Gershon $\mathrm{J}$ of the Second Division found in favour of the Museum, detailing the content of the First Amendment right to free speech, and holding that it clearly applied to the Museum. Gershon J stated that: "Governmental efforts to suppress expression can take many forms, and the courts have not hesitated to invalidate those efforts, no matter how indirect the form. ${ }^{, 56}$ When Giuliani

$52 \quad 64$ F.Supp.2d 184.

53 Merryman, Urice and Elsman Law, Ethics and the Visual Arts 5ed (2007) 734. See too "Sensation Sparks New York Storm" 23 September 1999 BBC http://news.bbc.co.uk/2/ hi/entertainment/ 455902.stm accessed April 2011.

54 See http://www.brooklynmuseum.org/opencollection/collections/ accessed March 2011.

55 From the perspective of this article, it is interesting to note that, once again, the trouble in this case seems to have been related to elephants!

56 Brooklyn Institute of Arts and Sciences 26. 
acknowledged that his decision to terminate funding to the Museum was based on an objection to both the content of the exhibit and the also the particular viewpoints expressed, Gershon held that this was utterly improper, stating as follows:

"There is no Federal constitutional issue more grave than the effort by government officials to censor works of expression and to threaten the vitality of a major cultural institution, as punishment for failing to abide by government demand for orthodoxy."

And further:

"There can be no greater showing of a First Amendment violation ... Indeed, the notion that government officials can stifle expression in order to protect the public good reverses our most basic principles.

Following this decision, Mayor Giuliani claimed that the judge had "lost all reason", and the City filed a brief on appeal to the United States Court of Appeals for the Second Circuit on November 24, 1999. ${ }^{59}$ After a heated sixmonth legal clash between the City and the Brooklyn Museum, both sides eventually reached a settlement on March $27,1999 .{ }^{60}$ The deal restored all New York City funding previously allocated to the Museum, but left unanswered many of the issues relating to the power of Government to interfere in art.

A similar and related case (on which the Court in Giuliani relied) concerned the Cuban Museum of Arts and Culture. ${ }^{61}$ In this case, the City of Miami objected to the exhibition in the Museum of Cuban artists who were "either living in Cuba or who had not denounced Fidel Castro". The City therefore refused to renew the lease of the Museum. However, when the Museum challenged this decision, it was held that the fact that the exhibits in question were highly offensive to a large segment of the Cuban population of Miami did not affect the fact that the exhibition was fully protected by the First amendment, and furthermore that the absence of a "right" to renewal of the lease did not defeat the first Amendment claim.

Yet another interesting American case, demonstrating once again how controversial and difficult it is to draw the line in such cases, is that of the performance artist Karen Finley and three others. ${ }^{62}$ This case involved a challenge to a statute passed by Congress which required the National Endowment of the Arts (the main subsidizer of the arts in America) to take "into consideration general standards of decency" when allocating public

57 Brooklyn Institute of Arts and Sciences 15.

58 Brooklyn Institute of Arts and Sciences 27.

59 See Barstow "Oct. 31 - Nov. 6; A Ruling Against Giuliani” 7 November 1999 New York Times B2.

60 Whyte "New York's Mayor Giuliani and the Brooklyn Museum Reach a Settlement" 31 March 2000 http://www.wsws.org/articles/2000/mar2000/muse-m31.shtml accessed March 2011.

61 Cuban Museum of Arts and Culture, Inc $v$ City of Miami 766 F. Supp. 1121 (S.D. Fla. 1991).

62 National Endowment for the Arts v Finley 524 U.S. 569 (1998). 
funds to artists. Karen Finley and three other artists challenged the statute when they were denied funding, despite initial approval by a National Endowment of the Arts' peer review process, because their work violated the "general standards of decency" requirement in the Act. Finley's work, in particular, was objected to because her "art" consisted of covering her naked body in chocolate and honey, and posing as a muse. In this case, the Supreme Court split. The conservative majority held that there was nothing wrong with a state body being required to take into consideration "general standards of decency" when making funding decisions. Justice Souter, however, dissented on classic liberal grounds, saying that a fundamental rule of freedom of speech is that "viewpoint discrimination in the exercise of public authority over expressive activity is unconstitutional." ${ }^{.63}$

What of those cases, however, in which a state body in the United States of America actively commissions a work of art for public display? In such cases, the American courts seem to allow the state (as a direct patron) a greater "margin of appreciation" (although by no means carte blanche) to interfere. This is illustrated by the famous case of the sculptor Richard Serra and his "Tilted Arc" sculpture in New York City. Interestingly, certain of the facts of this case are similar to case of the "Durban elephants" under discussion in this article, although there are significant differences between the facts pertaining to the two cases. In Serra $v$ United States General Services Administration, ${ }^{64}$ the General Services Administration (GSA) was sued by the artist Richard Serra, for removing his controversial sculpture Tilted Arc from 26 Federal Plaza in Lower Manhattan, the site for which it had been commissioned in 1981. Tilted Arc was a huge (120ft long, 12ft high) slab of unfinished, raw Corten steel weighing 73 tons. It was placed at an angle (something like the Leaning Tower of Pisa), sloping precariously towards the Jacob K Javits Federal Building.

The work received a hostile public reception almost from the moment it was opened - both on the ground of the sculpture's appearance and also on the ground that it obstructed Federal Plaza's previously open space. ${ }^{65}$ After several years of complaints, the GSA held a public hearing on the possible relocation of the sculpture. Following the 1989 hearing (at which Serra was himself represented), a report was drafted in which it was recommended that Tilted Arc should be relocated, and the new site for the sculpture should be chosen by a panel (including Serra). However, Serra was outraged at this suggestion, and claimed that, because the sculpture was site-specific, to remove it would be the equivalent of destroying the piece. ${ }^{66}$

Serra retaliated by filing a lawsuit against GSA, seeking a declaratory judgment that his rights had been violated, an injunction against the removal

\footnotetext{
National Endowment for the Arts $v$ Finley supra par 1-2.

847 F.2d 1045 (2d Cir. 1988).

The United States Court of Appeals, Second Circuit helpfully records: "The pigeons had barely begun to roost on "Tilted Arc" before the sculpture became the object of intense public criticism." Serra v United States General Services Administration supra par 6.

66 Andries Botha has a similar attitude to the proposed construction of the "Big Five".
} 
of the sculpture, and damages in excess of $\$ 30,000,000$. Serra's arguments were based on alleged breach of contract, trademark violations, copyright infringement and the violations of his First and Fifth Amendment rights to free speech and due process respectively. Serra argued that the work was site-specific, and therefore is "meaningful only when displayed in the location for which it is created" and was not intended to be displayed in more than one place. ${ }^{67}$ However, the courts found otherwise. First, looking at the contract between Serra and the GSA, it found that "all designs, sketches, models, and the work produced under this Agreement ... shall be the property of [the United States]" and did not limit the Government's use of the sculpture after it was purchased. ${ }^{68}$

The Appeal Court then held that the First Amendment has only limited application in a case such as this, where the artistic expression belongs to the Government rather than a private individual. ${ }^{69}$ The court held that in this case the Government (and not Serra) was the speaker, and that if Serra had wished to retain some degree of control as to the duration and location of the display of his work, he should have bargained for such rights when the contract was concluded. Moreover, according to the Court, "the First Amendment protects the freedom to express one's views, not the freedom to continue speaking forever". ${ }^{7}$

The court stressed repeatedly that the decision to remove Tilted Arc was not a "content based" decision - in other words it had nothing to do with the artistic merit, content or message of the sculpture itself. The primary reason for its removal was the functional fact that it interfered with the public's use of Federal Plaza. ${ }^{71}$ After months of legal wrangling, the Second Division Appellate Division confirmed the original decision, and Tilted Arc was removed from the plaza in which it had stood.

It is submitted that there are lessons for South Africa to be learnt from this case. The decision to remove Serra's sculpture was not based on the instruction of a particular political party, or even on the perceived will of the people. It was made only after an independent, public hearing at which representations were made on behalf of both sides. The decision was not quick, and the artist was involved in the determination of a site for relocation of the sculpture. Principles and procedural requirements of administrative law were closely followed. The court furthermore states, in clear terms, that mere political distaste for the work in question could never justify a decision to remove an artwork:

"We recognize that courts considering First Amendment challenges by artists to governmental decisions to remove purchased works of art must proceed with some caution, lest a removal ostensibly based on unsuitable physical

67 Serra v United States General Services Administration supra par 3.

68 Serra v United States General Services Administration supra par 4.

69 Serra v United States General Services Administration supra par 12.

70 Serra v United States General Services Administration supra par 17.

71 Serra v United States General Services Administration supra par 9. 
characteristics of the work or an unfavourable assessment of its aesthetic appeal camouflage an impermissible condemnation of political viewpoint."

\section{CONCLUSION}

In part one of this article, using the ongoing case of Andries Botha and his Durban elephants as a lens, we have raised as a central question the extent to which state officials, in the context of post-apartheid South Africa, should be entitled to determine the nature of and/or interfere in the creation of a public work of art. We have attempted to outline the broad parameters within which we believe the general debate on the question of state interference in public art ought to take place, by examining the historical, ideological, political and constitutional context of post-apartheid South Africa, as well as reviewing certain prominent North American cases on the issue. Bearing in mind this general context, which we firmly believe will shape the thinking of our courts on such issues, we shall proceed in part two of this article to examine certain of the specific legal questions which arise.

72 Serra v United States General Services Administration supra par 22. 